\title{
KARA UMOWNA A ZASTRZEŻENIE GWARANCYJNE
}

\section{Wstęp}

Kara umowna stanowi jedno z najczęściej stosowanych tzw. dodatkowych zastrzeżeń umownych, zwłaszcza w obrocie profesjonalnym. Takie postanowienie, prawidłowo skonstruowane, zgodnie $\mathrm{z}$ art. 483-484 Kodeksu cywilnego (dalej: K.c.) istotnie zabezpiecza interes wierzyciela. Możliwość modyfikacji zakresu odpowiedzialności dłużnika powoduje, że również odpowiedzialność z tytułu kary umownej może opierać się na innych okolicznościach niż przewidziane w art. 471 K.c. W skrajnym przypadku prowadzi to do rozszerzenia odpowiedzialności dłużnika do granic odpowiedzialności absolutnej. Celem niniejszego opracowania jest rozróżnienie dwóch instytucji prawa cywilnego, które określają granice odpowiedzialności dłużnika za niewykonanie lub nienależyte wykonanie zobowiązania, szczególnie że zastrzeżenie gwarancyjne nie było przedmiotem omówienia w doktrynie.

\section{Konstrukcja kary umownej}

Definicja kary umownej została zawarta w art. $483 \S 1$ K.c., zgodnie z którym jest to zastrzeżenie w umowie dotyczące naprawienia szkody wynikłej z niewykonania lub nienależytego wykonania zobowiązania

\footnotetext{
* Dr hab., prof. Europejskiej Wyższej Szkoły Prawa i Administracji w Warszawie; e-mail: tszancilo@ewspa.edu.pl, https://orcid.org/0000-0001-6015-6769.
} 
niepieniężnego przez zapłatę określonej sumy. Na podstawie treści tego przepisu można określić elementy przedmiotowo istotne (essentialia negotii) tej instytucji, przy czym musi istnieć ważna umowa, z której wynika obowiązek jej zapłaty. Jeżeli umowa z jakichkolwiek przyczyn jest nieważna (np. niezachowanie zasad reprezentacji czy formy ad solemnitatem do jej zawarcia), nie ma możliwości dochodzenia roszczeń z tytułu kary umownej.

Po pierwsze, musi zostać określone zobowiązanie o charakterze niepieniężnym, a przynajmniej pojedynczy obowiązek, którego niewykonanie lub nienależyte wykonanie rodzi obowiązek zapłaty kary. Strony powinny dokładnie określić okoliczności, z którymi zostaje powiązana możliwość naliczenia kar umownych, ale nie jest to wymóg niezbędny, warunkujący ważność postanowienia. Istotne jest, aby było możliwe ustalenie okoliczności, do której ma zastosowanie kara umowna. Wystarczające jest ogólne odwołanie się do „przejawu” niewłaściwego wykonania zobowiązania (bez sprecyzowania tego przejawu), co oznacza, że każde nienależyte wykonanie zobowiązania może skutkować obciążeniem dłużnika karą umowną, pod warunkiem jednak, że chodzi o zobowiązanie o charakterze niepieniężnym. Możliwe jest również zastrzeżenie kary umownej tylko do wypadków "poważnego” lub „rażącego" ${ }^{1}$, aczkolwiek wprowadzenie do umowy nieostrych pojęć rodzi konieczność wykładni, czy w konkretnej sytuacji zaszedł wypadek wskazanego naruszenia obowiązania.

Po drugie, niezbędne jest wskazanie kwoty, jaką w związku z niewykonaniem lub nienależytym wykonaniem umowy jest zobowiązany zapłacić dłużnik. W art. 483 § 1 K.c. jest mowa wprost o zastrzeżeniu kary umownej w „określonej sumie”. Musi zatem zostać wyrażona kwotowo. Nie jest przy tym niezbędne określenie wysokości kwoty kary umownej wprost, gdyż choć taka konstrukcja jest pożądana, to dopuszczalne jest posłużenie się innym miernikiem wysokości, np. ułamkiem wartości rzeczy albo ułamkiem innej sumy (np. wynagrodzenia), jeżeli ustalenie kwoty byłoby tylko czynnością arytmetyczną. $W$ takim bowiem przypadku mamy do czynienia $\mathrm{z}$ określoną sumą, wyrażoną jedynie $\mathrm{w}$ formie działania matematycznego. Wyłącza to np. zastrzeżenie kary umownej w odniesieniu do wynagrodzenia kosztorysowego, jako że nie jest możliwe ustalenie jej podstawy $w$ dacie zawarcia umowy, jak również nawet $w$ trakcie trwania robót (np. z powodu odstąpienia od umowy). Nie chodzi tu bowiem

1 Zob. szerzej J. Jastrzębski, Kara umowna, Warszawa 2006, s. 182. 
jedynie o wykonanie działania matematycznego, ale określenie podstawy naliczenia kary umownej. Możliwe jest zaś wprowadzenie innego miernika (np. szacunkowej wartości robót kosztorysowych).

Nie jest zatem dopuszczalne przyjęcie konstrukcji prawnej zakładającej ustalanie w przyszłości podstawy naliczania kary umownej². Jeżeli strony nie wskazały w umowie wprost jej kwoty, to w umowie musi zostać określona w jednoznaczny sposób podstawa do finalnego określenia jej wysokości, możliwa do obliczenia w momencie zawarcia umowy. Istotne jest, aby zarówno strony umowy, jak i następnie sąd rozpoznający sprawę byli w stanie obliczyć wysokość kary umownej. Oznacza to, że kara umowna powinna być możliwa do wyliczenia już w momencie zawarcia umowy, a jej wysokość nie powinna wymagać dowodzenia ${ }^{3}$. Dopuszczalne jest więc ustalenie kary umownej również w odniesieniu do niewykonanej części zobowiązania, jeżeli jest ustalona podstawa jej wyliczenia, np. w przypadku dostawy odniesienie jej do wartości niedostarczonej partii.

Nie można się przy tym zgodzić z poglądem wyrażonym przez Sąd Najwyższy w wyroku z dnia 22 października 2015 r. ${ }^{4}$, że nieokreślenie w umowie końcowego terminu naliczania kar umownych ani ich kwoty maksymalnej prowadzi do obciążenia zobowiązanego tym świadczeniem $\mathrm{w}$ nieokreślonym czasie, a zatem $\mathrm{w}$ istocie tworzy zobowiązanie wieczne, niekończące się, a takie ukształtowanie zobowiązania zapłaty kary umownej nie spełnia wymagania określenia sumy pieniężnej z art. 483 $\S 1$ K.c. Należy bowiem zauważyć, że dla kary umownej związanej z nieterminowym wykonaniem zobowiązania nie jest możliwe określenie przy zawarciu umowy okresu zwłoki. Wymóg oznaczenia "określonej sumy” spełnia odniesienie jej do okresu czasu (zwykle dnia), albowiem w przeciwnym razie nie byłoby możliwe w ogóle zastrzeżenie kary umownej z tego tytułu (wprowadzenie do umowy górnej granicy oznaczałoby tylko określenie maksymalnej kwoty, jaką wierzyciel mógłby żądać od dłużnika $z$ tego tytułu, ale nie zmieniałoby istoty rzeczy, tj. że suma jest znana dopiero w momencie, gdy znany jest okres zwłoki). Tak naprawdę, dochodzi tu do zsumowania kar umownych za poszczególne okresy. Co więcej, kara umowna należy się w sytuacji, gdy dłużnik odpowiada za okoliczności

2 Wyrok SN z dnia 8 lutego 2007 r., I CSK 420/06, LEX nr 274239; odmiennie SN w wyroku z dnia 15 listopada 2012 r., V CSK 515/11, LEX nr 1276233.

3 Zob. wyrok SN z dnia 3 października 2019 r., I CSK 280/18, LEX nr 2746892.

4 IV CSK 687/14, LEX nr 1943856. 
leżące u podstaw niewykonania lub nienależytego wykonania zobowiązania. W takiej sytuacji dłużnik mógłby odmówić spełnienia świadczenia i byłby zwolniony $z$ obowiązku zapłaty kary umownej. Trzeba również zauważyć, że wierzyciel nie jest zobowiązany do odstąpienia od umowy (jej wypowiedzenia) z przyczyn leżących po stronie dłużnika, stanowi to bowiem jego uprawnienie, a nie obowiązek (chociaż nieskorzystanie z tego prawa może mieć wpływ na zastosowanie art. 5 K.c., jeżeli będzie dochodził roszczenia z tytułu kary umownej). Nadto naliczeniu rażącej kary umownej przeciwdziała instytucja miarkowania (art. $484 \S 2$ K.c.), a upływ terminu przedawnienia pozwala uchylić się od jej zapłaty w całości lub części. Co więcej, postanowienie dotyczące kary umownej może zostać uznane za nieważne na podstawie art. 58 § 2 K.c. Istnieją więc instytucje, które uniemożliwiają naliczenie kary umownej w zbyt wysokiej kwocie.

W związku z tym, jeżeli w powyższej sytuacji można byłoby mówić o nieważności postanowienia zastrzegającego karę umowną, to jedynie z punktu widzenia kreowania zobowiązań o charakterze „wiecznym”, jako sprzecznego $\mathrm{z}$ art. $353^{1}$ K.c. (istotą prawa zobowiązań jest bowiem możliwość wystąpienia ze stosunku prawnego). In casu takie postanowienie mogłoby zostać uznane za nieważne w części przekraczającej faktyczną potrzebę zastosowania instytucji kary umownej - jako sprzeczne z naturą (właściwością) stosunku zobowiązaniowego (art. 483 § 1 w zW. z art. 58 $\S 1$ i 3 K.c. $)^{5}$. Generalnie jednak należy opowiedzieć się za ważnością takiego postanowienia (bez określenia końcowego terminu naliczania kar umownych ani ich kwoty maksymalnej). Jeżeli natomiast strony ustalą w umowie górny limit kary umownej, nadal może znaleźć zastosowanie instytucja miarkowania (art. 484 § 2 K.c.).

\section{Ogólne zasady odpowiedzialności dłużnika}

Ponieważ przepisy prawa zobowiązań mają - co do zasady - dyspozytywny charakter, to również w odniesieniu do granic odpowiedzialności kontraktowej istnieje możliwość zmiany ustawowych uregulowań.

\footnotetext{
5 Z powołanym wyrokiem SN nie można jednak zgodzić się również z tej przyczyny, że w realiach sprawy nie została tak naprawdę zastrzeżona kara umowna, bowiem postanowienie umowne nie odnosiło się w ogóle do zobowiązania w rozumieniu art. 353 § 1 K.c.
} 
Dotyczy to w szczególności art. 471 K.c., na podstawie którego dłużnik jest zobowiązany naprawić szkodę wynikłą z niewykonania lub nienależytego wykonania zobowiązania, chyba że niewykonanie lub nienależyte wykonanie jest następstwem okoliczności, za które dłużnik odpowiedzialności nie ponosi. Jeżeli dłużnik wykonuje zobowiązanie za pomocą innej osoby (podwykonawcy), jest odpowiedzialny za jej działanie lub zaniechanie jak za własne (art. 474 K.c.). Dochodząc odszkodowania na podstawie art. 471 K.c., wierzyciel musi udowodnić fakt niewykonania lub nienależytego wykonania zobowiązania, powstanie szkody w określonej wysokości oraz normalny związek przyczynowy między naruszeniem przez dłużnika więzi zobowiązaniowej a szkodą wyrządzoną wierzycielowi, a jeżeli odpowiedzialność wynika z umowy (kontraktu) - także istnienie ważnej umowy. Nieudowodnienie przez wierzyciela którejkolwiek z tych przesłanek musi skutkować oddaleniem powództwa.

Konstrukcja art. 471 K.c. przesądza przy tym, że w orzecznictwie i doktrynie przyjmuje się jednolicie, iż przyjęcie odpowiedzialności dłużnika na podstawie tego przepisu nie jest uzależnione od udowodnienia przez wierzyciela, że nienależyte wykonanie zobowiązania jest następstwem okoliczności, za które dłużnik ponosi odpowiedzialność. To dłużnik, aby uwolnić się od odpowiedzialności, powinien udowodnić zaistnienie takich okoliczności faktycznych, które w okolicznościach sprawy dadzą podstawę do oceny, że niewykonanie lub nienależyte wykonanie zobowiązania było następstwem okoliczności, za które nie ponosi on odpowiedzialności ${ }^{6}$. Wynika to stąd, że w art. 471 K.c. zastosowano konstrukcję tzw. domniemanej winy dłużnika, co powoduje zmianę (odwrócenie) ciężaru dowodu wynikającego z art. 6 K.c. i art. 232 zd. 1 Kodeksu postępowania cywilnego (dalej: K.p.c.). W związku z tym wykazanie przez wierzyciela przesłanek kontraktowej odpowiedzialności odszkodowawczej aktualizuje potrzebę obrony dłużnika, który może wykazać, że niewykonanie lub nienależyte wykonanie zobowiązania jest następstwem okoliczności, za które nie ponosi on odpowiedzialności ${ }^{7}$, a więc że nie

6 Zob. np. wyroki SN z dnia 9 stycznia 2002 r., V CKN 630/00, LEX nr 54329 i z dnia 5 grudnia 2008 r., III CSK 211/08, LEX nr 484728; wyrok SA w Szczecinie z dnia 17 lipca 2014 r., I ACa 234/14, LEX nr 1527215.

7 Zob. np. wyroki SN z dnia 18 lutego 2009 r., I CSK 327/08, LEX nr 560505 i z dnia 24 czerwca 2013 r., II PK 344/12, LEX nr 1350304; wyrok SA w Poznaniu z dnia 
ponosi winy. Domniemanie ma zatem charakter wzruszalny (praesumptio iuris tantum), przy czym w orzecznictwie przeważa pogląd, że aby uznać, iż taki dowód został skutecznie przeprowadzony, konieczne jest jednak ustalenie - na podstawie dowodów przeprowadzonych w sprawie, po dokonaniu ich oceny (art. 233 § 1 K.p.c.) - konkretnych okoliczności o tym świadczących ${ }^{8}$. Nie wystarczy zatem powołać się ogólnie na prawidłowe wykonanie zobowiązania. W doktrynie został jednak wyrażony pogląd, że dłużnik nie musi wykazać konkretnej przyczyny niewykonania lub nienależytego wykonania zobowiązania, o ile wykaże, że w określonej sytuacji dołożył należytej staranności ${ }^{9}$.

Zasadne jest przyjęcie, że dłużnik może zwolnić się od odpowiedzialności (ekskulpować) zarówno wówczas, gdy wykaże, że określona przyczyna naruszenia obowiązku wynikła z okoliczności, za które nie ponosi odpowiedzialności, jak i wtedy, gdy wykaże dochowanie należytej staranności przy wykonywaniu zobowiązania niezależnie od tego, jaka była faktyczna przyczyna naruszenia zobowiązania ${ }^{10}$. W niektórych wypadkach może nie być możliwe udowodnienie konkretnej przyczyny niewykonania lub nienależytego wykonania zobowiązania, ale jeżeli dłużnik odpowiada na zasadzie winy, to bardzo istotny jest art. 355 K.c., zawierający definicję należytej staranności. Jeżeli bowiem dłużnik dochował należytej staranności, nie można mu postawić zarzutu winy nawet $\mathrm{w}$ najlżejszym stopniu (niedbalstwa).

Jeżeli natomiast odpowiedzialność dłużnika kształtuje się na zasadzie ryzyka, konieczne jest wykazanie przez niego jednej z okoliczności (przesłanek) egzoneracyjnych. Chodzi o siłę wyższą, wyłączną winę poszkodowanego lub wyłączną winę osoby trzeciej (tzw. klasyczne

8 marca 2007 r., I ACa 29/07, LEX nr 370925; wyrok SA w Lublinie z dnia 19 lutego 2013 r., I ACa 717/12, LEX nr 1314796.

8 Zob. np. wyroki SN: z dnia 20 listopada 1979 r., IV CR 376/79, OSNCP 1980, nr 4, poz. 80; z dnia 9 stycznia 2002 r., V CKN 630/00, LEX nr 54329; z dnia 5 grudnia 2008 r., III CSK 211/08, LEX nr 484728; wyrok SA w Szczecinie z dnia 17 lipca 2014 r., I ACa 234/14, LEX nr 1527215.

9 Zob. np. T. Pajor, Odpowiedzialność dtużnika za niewoykonanie zobowiazania, Warszawa 1982, s. 277 i n.

10 Zob. też wyrok SN z dnia 9 stycznia 2002 r., V CKN 630/00, LEX nr 54329 oraz z dnia 7 lipca 2005 r., V CK 869/04, LEX nr 150649; T. Wiśniewski, w: Kodeks cywilny. Komentarz, t. 3. Zobowiązania. Część ogólna, red. J. Gudowski, Warszawa 2018, art. 471 pkt 8. 
okoliczności egzoneracyjne), ewentualnie inne okoliczności wynikające z przepisu szczególnego ${ }^{11}$.

W przypadku kary umownej zakres odpowiedzialności pokrywa się w pełni z zakresem ogólnej odpowiedzialności dłużnika za niewykonanie lub nienależyte wykonanie zobowiązania (art. 471 K.c.). Z tego też względu przesłanki obowiązku zapłaty kary umownej określane są przez pryzmat ogólnych przesłanek kontraktowej odpowiedzialności odszkodowawczej $^{12}$. Kara umowna stanowi bowiem surogat odszkodowania, z uwzględnieniem funkcji, które różnią ją od odszkodowania ${ }^{13}$. Oznacza to, że wierzyciel nie może skutecznie dochodzić zapłaty kary umownej, jeżeli dłużnik nie ponosi odpowiedzialności za niewykonanie lub nienależyte wykonanie zobowiązania. W celu zwolnienia się z odpowiedzialności dłużnik powinien zatem wykazać, że określona przyczyna naruszenia obowiązku wynikła z okoliczności, za które nie ponosi odpowiedzialności, lub że dochował należytej staranności przy wykonywaniu zobowiązania, ewentualnie zaszła okoliczność egzoneracyjna.

\section{Modyfikacja odpowiedzialności dłużnika}

Ogólne granice odpowiedzialności dłużnika mogą być modyfikowane umownie przez strony - w ramach art. $353^{1}$ K.c. - na co wprost zezwala art. 473 § 1 K.c., przy czym w $\S 2$ tego artykułu ustawodawca wyznaczył minimalne granice tej odpowiedzialności, co oznacza, że strony nie mogą skutecznie ustalić, iż dłużnik nie będzie odpowiedzialny za szkodę, którą może wyrządzić wierzycielowi umyślnie. Podkreśla się przy tym słusznie, że modyfikacja odpowiedzialności na podstawie art. 473 K.c. musi być wyraźnie przewidziana $\mathrm{w}$ postanowieniach umownych $^{14}$, ale ustalenia

11 Zob. np. art. 65 ust. 2 i 3 ustawy z dnia 15 listopada 1984 r. - Prawo przewozowe (tekst jednolity: Dz. U. z 2020 r. poz. 8).

12 Zob. np. wyrok SN z dnia 11 stycznia 2008 r., V CSK 362/07, OSP 2012, z. 7-8, poz. 76.

13 Zob. szerzej T. Szanciło, w: Kodeks cywilny. Komentarz, red. M. Załucki, Warszawa 2019, s. 1113.

14 Zob. np. wyrok SN z dnia 8 lipca 2004 r., IV CK 583/03, LEX nr 137571; wyrok SA w Białymstoku z dnia 8 czerwca 2016 r., I ACa 116/16, LEX nr 2071291. 
stron nie mogą być sprzeczne z właściwością (naturą) stosunku, ustawą lub zasadami współżycia społecznego (art. $353^{1}$ K.c.).

Jest to o tyle istotne, że dochodzi do zmiany kodeksowych zasad odpowiedzialności, co powinno być rozpatrywane przy zastosowaniu art. $58 \S 1 \mathrm{w}$ zW. z art. 473 § 2 K.c. - jeżeli strony wyłączyłyby odpowiedzialność za szkodę wyrządzoną umyślnie, lub art. 58 § 2 w zw. z art. 473 $\S 1$ K.c. - jeżeli modyfikacja byłaby sprzeczna z zasadami współżycia społecznego. Skutek wprowadzenia klauzuli modyfikującej odpowiedzialność dłużnika może być zależny od statusu stron umowy. Jeżeli umowę zawiera przedsiębiorca $\mathrm{z}$ konsumentem, przyjęcie przez przedsiębiorcę szerszej odpowiedzialności $\mathrm{w}$ stosunku do konsumenta powinno być zwykle uznane za prawnie wiążące, gdyż raczej nie będzie miała zastosowania żadna z przesłanek wymienionych w art. $353^{1}$ K.c. Jeżeli natomiast do umowy (także zawieranej za pomocą wzorca umowy) zostanie wprowadzona klauzula ograniczająca odpowiedzialność przedsiębiorcy lub rozszerzająca odpowiedzialność konsumenta, może to być niedozwolone postanowienie umowne (klauzula abuzywna) w rozumieniu art. $385^{1}$ K.c. (z uwzględnieniem art. $385^{3}$ pkt 2 K.c.), chyba że zostanie ono uznane za nieważne ${ }^{15}$.

Takie postanowienie (mogące być uznane za abuzywne) wiąże natomiast $\mathrm{w}$ obrocie profesjonalnym (między dwoma przedsiębiorcami) i dwustronnie nieprofesjonalnym, dlatego że nie stosuje się do nich konstrukcji niedozwolonych postanowień umownych. W związku z tym podstawowe znaczenie ma tu art. $353^{1}$ K.c., a więc zasada swobody umów i prymat woli stron. Dokonując oceny konkretnego postanowienia modyfikującego odpowiedzialność w trybie art. 473 K.c., tj. zaostrzającego lub łagodzącego odpowiedzialność dłużnika w stosunku do zasad ogólnych, sąd powinien wziąć pod uwagę, że chodzi o odstępstwo od ogólnych zasad wynikających z art. 471 K.c. (jeżeli chodzi o zasadę winy) lub z innych przepisów, które regulują odpowiedzialność na podstawie zasady ryzyka lub tzw. odpowiedzialność absolutną. Ponieważ istnieje ustawowa podstawa do modyfikacji odszkodowawczej odpowiedzialności

15 Na temat wzajemnego stosunku nieważności i abuzywności zob. uchwałę SN z dnia 13 stycznia 2011 r., III CZP 119/00, OSNC 2011, nr 9, poz. 95; także np. wyrok SN z dnia 20 stycznia 2011 r., I CSK 218/10, Monitor Prawniczy 2011, nr 18, s. 997; wyroki SA w Warszawie z dnia 21 listopada 2012 r., VI ACa 824/12, LEX nr 1289817 oraz z dnia 26 marca 2014 r., VI ACa 1086/13, LEX nr 1499066. 
dłużnika, w praktyce stosunkowo rzadko zachodzi sprzeczność omawianego postanowienia umownego $\mathrm{z}$ przepisami prawa (np. $\mathrm{w}$ razie sprzeczności z art. 473 § 2 K.c.), ale również jego ukształtowanie w celu obejścia ustawy, czyli takie ukształtowanie jego treści, która z punktu widzenia formalnego (pozornie) nie sprzeciwia się ustawie, ale w rzeczywistości (w znaczeniu materialnym) zmierza do zrealizowania celu, którego osiągnięcie jest przez nią zakazane - chodzi tu zatem o wywołanie skutku sprzecznego z prawem ${ }^{16}$.

Zdecydowanie częściej należy rozważyć, czy takie postanowienie nie jest sprzeczne z zasadami współżycia społecznego (zwanymi w obrocie profesjonalnym niejednokrotnie dobrymi obyczajami kupieckimi ${ }^{17}$. Odwołanie się do zasad współżycia społecznego oznacza odwołanie się do idei słuszności w prawie i do powszechnie uznawanych wartości w kulturze naszego społeczeństwa. Ujmując rzecz ogólnie, można przyjąć, że przez zasady współżycia społecznego należy rozumieć podstawowe zasady etycznego i uczciwego postępowania ${ }^{18}$. W orzecznictwie przeważa przy tym pogląd, że niezbędna jest konkretyzacja zasad współżycia społecznego na etapie postępowania sądowego, tzn. aby można było mówić o bezprawnym działaniu sprawcy, wierzyciel powinien wskazać, jakie zasady współżycia społecznego - w okolicznościach konkretnej sprawy - zostały naruszone. $W$ konsekwencji, rozstrzygając sprawę na podstawie naruszenia zasad współżycia społecznego, sąd nie może powołać się ogólnie, że doszło do naruszenia tych zasad, ale powinien wskazać, jaką konkretnie zasadę wziął pod uwagę, rozstrzygając w określony sposób ${ }^{19}$. Podzielić należy tu pogląd, zgodnie z którym obiektywnie niekorzystna dla jednej strony treść umowy zasługiwać będzie na

16 Zob. wyrok SN z dnia 25 listopada 2004 r., I PK 42/04, OSNP 2005, nr 14, poz. 209.

17 Na temat pojęcia zasad współżycia społecznego zob. szerzej P. Sobolewski, w: Kodeks cywilny. Komentarz, red. K. Osajda, 2020 [baza danych Legalis], art. 58, Nb 94-100.

18 Zob. wyrok SN z dnia 28 listopada 2001 r., IV CKN 1756/00, LEX nr 80259; także np. A. Tomaszek, Dobre obyczaje w dziatalności gospodarczej, Palestra 1997, nr 9-10, s. 5 i n.; R. Stefanicki, Dobre obyczaje w prawie polskim, Przegląd Prawa Handlowego 2002, nr 5, s. 23 i n.; B. Janiszewska, Klauzula generalna dobrych obyczajów w znowelizowanych przepisach kodeksu cywilnego, Przegląd Prawa Handlowego 2003, nr 10, s. 12 i n.; E. Rott-Pietrzyk, Klauzula generalna rozsądku w kodeksie cywilnym, Kwartalnik Prawa Prywatnego 2005, t. 14, nr 3, s. 617 i n.

19 Zob. np. wyroki SN: z dnia 14 października 1998 r., II CKN 928/97, OSNC 1999, nr 4, poz. 75; z dnia 26 listopada 1999 r., III CKN 460/98, OSNC 2000, nr 5, poz. 100; z dnia 31 maja 2006 r., IV CSK 149/05, LEX nr 258681. 
negatywną ocenę moralną, a w rezultacie prowadzić do uznania umowy za sprzeczną z zasadami współżycia społecznego w sytuacji, gdy do takiego ukształtowania stosunku umownego, który jest dla niej w sposób widoczny krzywdzący, doszło przy świadomym lub tylko spowodowanym niedbalstwem wykorzystaniu przez drugą stronę swojej silniejszej pozycji. Umowa zawarta przez stronę działającą pod presją faktycznej przewagi kontrahenta nie może być bowiem uznana za wyraz w pełni swobodnej i rozważnie podjętej przez nią decyzji. Dominująca pozycja jednej ze stron umowy w stosunku do kontrahenta może być zarówno następstwem istniejącego między nimi stosunku zależności o charakterze ekonomicznym, czy też mającej źródło w stosunkach rodzinnych, jak i szczególnych okoliczności dotyczących osoby słabszego partnera związanych np. z jego chorobą, w przebiegu której następuje upośledzenie sfery motywacyjnej i decyzyjnej. Tak samo trzeba ocenić umowę zawartą w warunkach nacisku jednej strony przez wykorzystanie wpływów czy pozycji związanej z zajmowanym stanowiskiem, z którym wiąże się decydowanie o sytuacji kontrahentów ${ }^{20}$. Ma to miejsce w szczególności w przypadku, gdy pozycje kontraktowe stron nie były równe, jedna strona narzuciła warunki umowy drugiej, a więc nie było realnej możliwości negocjowania umowy, w wyniku czego zawarto w umowie asymetryczne postanowienia, tj. istotnie rozszerzono lub ograniczono odpowiedzialność tylko jednej strony.

W przypadku nieważności postanowienia rozszerzającego lub ograniczającego odpowiedzialność odszkodowawczą jednej ze stron ma zastosowanie art. 58 § 3 K.c., przy czym umowa pozostaje ważna w pozostałej części, bowiem w praktyce nie będzie zachodzić sytuacja, w której bez takiego postanowienia umowa nie zostałaby zawarta. Także w obrocie z konsumentem nieważność postanowienia umownego nie oznacza automatycznie nieważności umowy ${ }^{21}$.

20 Zob. wyroki SN z dnia 12 listopada 1974 r., I CR 602/74, OSP 1976, z. 7-8, poz. 143 i z dnia 18 marca 2008 r., IV CSK 478/07, Monitor Prawniczy 2011, nr 5, s. 279 oraz uchwałę SN z dnia 9 marca 1993 r., III CZP 27/93, OSP 1994, z. 2, poz. 2.

${ }^{21}$ Zob. wyrok SA w Warszawie z dnia 13 grudnia 2018 r., VI ACa 744/18, LEX nr 2668906. 


\section{Modyfikacja kary umownej}

Z treści art. 473 K.c. wynikają istotne wnioski. Po pierwsze, w przepisie wyznaczono granice modyfikacji odpowiedzialności dłużnika. Należy przy tym rozróżnić „dolną" i „górną" granicę odpowiedzialności dłużnika. Ta pierwsza wynika z treści art. 473 § 2 K.c., a więc strony nie mogą umownie wyłączyć odpowiedzialności dłużnika za szkodę, którą może wyrządzić wierzycielowi umyślnie. Chodzi tu zarówno o zachowanie dłużnika, które można zakwalifikować jako winę umyślną w zamiarze bezpośrednim (dolus directus), jak i w zamiarze ewentualnym (dolus eventualis), i to bez względu na to, czy szkodę wyrządzi sam dłużnik, czy też osoba, za pośrednictwem której wykonuje zobowiązanie ${ }^{22}$, a więc podwykonawca (art. 474 K.c.). Postanowienie umowne sprzeczne z powołanym przepisem będzie nieważne (art. 58 § $1 \mathrm{w}$ zw. z art. 473 § 2 K.c.).

Po drugie, w art. 473 K.c. nie określono "górnej” granicy modyfikacji ustawowego wzorca odpowiedzialności dłużnika. Oznacza to, że w przeciwieństwie do ograniczenia odpowiedzialności, rozszerzenie odpowiedzialności dłużnika jest nieograniczone, zatem w umowie może zostać przewidziana absolutna odpowiedzialność dłużnika za szkody - wówczas dłużnik nie może zwolnić się od odpowiedzialności (ani w drodze ekskulpacji, ani egzoneracji). Nie można przy tym zapominać, że przyczyna niewykonania lub nienależytego wykonania zobowiązania może leżeć po stronie wierzyciela. Przyjęcie bezwzględnego (absolutnego) charakteru odpowiedzialności dłużnika oznaczałoby, że odpowiada on również za szkody spowodowane okolicznościami, za które odpowiedzialność ponosi wierzyciel. Innymi słowy, działanie lub zaniechanie wierzyciela (jak i jego podwykonawców - art. 474 K.c.) spowodowałoby niemożność spełnienia świadczenia przez dłużnika, a mimo to wierzyciel byłby uprawniony do dochodzenia określonej w umowie kwoty, ewentualnie odszkodowania, ale już nie na zasadach ogólnych, lecz określonych w umowie. Godziłoby to $\mathrm{w}$ istotę odpowiedzialności odszkodowawczej (a przynajmniej byłoby sprzeczne z zasadami współżycia społecznego, w szczególności lojalności kontraktowej). Nie sposób bowiem wówczas mówić o niewykonaniu lub nienależytym wykonaniu zobowiązania przez „dłużnika”, skoro to

22 Zob. wyrok SA w Gdańsku z dnia 25 października 1996 r., I ACr 822/96, OSA 1997, z. 10, poz. 58; W. Warkałło, Klauzule wyłaczające odpowiedzialność za szkodę a ubezpieczenie odpowiedzialności cywilnej, Ruch Prawniczy, Ekonomiczny i Socjologiczny 1974, nr 3, s. 328. 
wierzyciel stałby się dłużnikiem. Poza tym od woli jednej ze stron (w przypadku winy umyślnej) zależałoby, czy druga strona poniesie odpowiedzialność odszkodowawczą, a ponadto jedna ze stron musiałaby naprawić szkodę nawet wówczas, gdyby kontrahent wyrządził ją w zamiarze bezpośrednim. Takie postanowienie umowne byłoby nieważne (art. 58 $\S 1 \mathrm{w}$ zw. z art. $353^{1}$ K.c.). Nie można zatem rozszerzyć odpowiedzialności dłużnika przez obciążenie go okolicznościami, za które wierzyciel ponosi odpowiedzialnośćc ${ }^{23}$. W konsekwencji postanowienie dotyczące kary umownej w tej części również należałoby uznać za nieważne. Nie ma natomiast przeszkód, aby obciążyć umownie dłużnika za okoliczności, za które żadna ze stron umowy nie ponosi odpowiedzialności.

Po trzecie, w art. $473 \S 1$ K.c. zastrzeżono, że modyfikacja odpowiedzialności dłużnika może dotyczyć oznaczonych okoliczności skutkujących niewykonaniem lub nienależytym wykonaniem zobowiązania, za które na mocy ustawy odpowiedzialności nie ponosi. W związku z tym $\mathrm{w}$ orzecznictwie dominuje pogląd, że zaostrzając - na podstawie tego przepisu - odpowiedzialność dłużnika przez oderwanie jej od zasady winy, muszą w umowie ściśle określić mające uzasadniać odpowiedzialność dłużnika okoliczności, niemieszczące się w granicach wyznaczonych przez art. 472 K.c.; nie ma bowiem podstaw do dorozumienia rozszerzonej odpowiedzialności dłużnika ${ }^{24}$. Także w doktrynie - powołując się na literalne brzmienie art. 473 § 1 K.c. - podkreśla się, że w celu skutecznego umownego rozszerzenia zakresu odpowiedzialności dłużnika niezbędne jest wskazanie w umowie okoliczności, które mają obciążać dłużnika, a wykraczają poza ustawowy wzorzec odpowiedzialności ${ }^{25}$.

Taki pogląd jest słuszny, jeżeli chodzi o konstrukcję kary umownej. Jak przyjęto $\mathrm{w}$ orzecznictwie, przepisy o karze umownej mają charakter

23 Zob. też wyrok SN z dnia 27 września 2013 r., I CSK 748/12, OSNC 2014, nr 6, poz. 67.

24 Zob. np. tamże oraz wyrok SN z dnia 16 listopada 2017 r., V CSK 28/17, LEX nr 2447351; wyroki SA w Szczecinie z dnia 17 lutego 2016 r., I ACa 1099/15, LEX nr 2052661 i z dnia 21 czerwca 2017 r., I ACa 118/17, LEX nr 2396160; wyrok SA w Białymstoku z dnia 15 lutego 2019 r., I ACa 548/18, LEX nr 2669364.

25 M. Piekarski, w: Kodeks cywilny. Komentarz, t. 2, red. Z. Resich, J. Ignatowicz, J. Pietrzykowski, I. Bielski, Warszawa 1972, s. 1167; W. Popiołek, w: Kodeks cywilny, t. 2. Komentarz. Art. 450-1088. Przepisy wprowadzajace, red. K. Pietrzykowski, Warszawa 2018, art. 473, $\mathrm{Nb} 1$. 
dyspozytywny ${ }^{26}$, przy czym należy pamiętać, że nie dotyczy to kwestii charakteru świadczenia, którego niewykonanie lub nienależyte wykonanie może stanowić podstawę naliczenia kary umownej oraz obowiązku określenia jej wysokości w momencie zawarcia umowy. W umowie strony mogą zatem postanowić, że kara umowna zostanie naliczona w sytuacji, gdy zaistnieje nie tylko zwłoka po stronie dłużnika, a więc tzw. opóźnienie kwalifikowane, czyli będące następstwem okoliczności, za które dłużnik ponosi odpowiedzialność (art. 476 K.c.), ale również gdy np. niewykonanie umowy w terminie będzie wynikiem niesprzyjających warunków atmosferycznych, bez względu na to, czy przy dochowaniu należytej staranności (zwykle przy zastosowaniu art. 355 § 2 K.c.) dłużnik mógł przewidzieć ich wystąpienie. Wprowadzenie tego rodzaju dodatkowej okoliczności rozszerza bowiem granice odpowiedzialności dłużnika poza ramy wyznaczone art. $483 \S 1 \mathrm{w}$ zw. z art. 471 K.c. Strony mogą więc w ramach zasady swobody umów zastrzec w umowie karę umowną nie tylko w przypadku niewykonania lub nienależytego wykonania zobowiązania przez dłużnika z przyczyn, za które ponosi on odpowiedzialność, ale i za dodatkowe okoliczności, które tego wymogu nie spełniają, za wyjątkiem okoliczności, za które odpowiedzialność ponosi wierzyciel.

Po czwarte, brzmienie $\S 2$ art. 473 K.c. jest odmienne niż jego § 1, gdyż brak jest w nim zastrzeżenia, że aby ograniczyć odpowiedzialność dłużnika, strony muszą enumeratywnie wymienić okoliczności, za które dłużnik nie będzie ponosił odpowiedzialności. Mogą tak uczynić, niemniej wystarczające jest ogólne sformułowanie, jak wyłączenie odpowiedzialności za: 1) okoliczności wynikające z winy nieumyślnej, a więc zarówno gdy zachowanie dłużnika spełnia znamiona niedbalstwa, jak i rażącego niedbalstwa; 2) nieumyślne zachowanie samego dłużnika, pozostawiając jego odpowiedzialność za zachowanie podwykonawców; 3) nieumyślne zachowanie podwykonawców, pozostawiając odpowiedzialność dłużnika bez zmian. Można przyjąć w umowie także odpowiedzialność dłużnika na zasadzie ryzyka zamiast na zasadzie winy (co pozwala jedynie na egzonerację, a nie ekskulpację). W żadnej z tych sytuacji nie wskazuje się wprost okoliczności, za które dłużnik odpowiada, niemniej dochodzi do ograniczenia jego odpowiedzialności, a zakres tej odpowiedzialności jest możliwy do określenia in casu. W każdym wypadku niezbędne jest

26 Zob. np. wyroki SN z dnia 26 czerwca 2012 r., II CSK 84/12, LEX nr 1232233 oraz z dnia 16 stycznia 2013 r., II CSK 331/12, LEX nr 1293724. 
przy tym, aby wynikiem takiego zachowania (działania lub zaniechania) była szkoda pozostająca w normalnym (adekwatnym) związku przyczynowym z tym zachowaniem (art. $361 \S 1$ K.c.).

\section{Istota zastrzeżenia gwarancyjnego}

Przyjęcie zaprezentowanej wyżej koncepcji o konieczności wskazania w każdym przypadku konkretnych okoliczności, za które dłużnik ponosi odpowiedzialność, oznaczałoby jednak niemożność ustanowienia w drodze umowy odpowiedzialności o charakterze absolutnym. Kazuistyczne wymienienie wszystkich takich okoliczności jest bowiem oczywiście niemożliwe. Wskazuje się, że nie jest możliwe obciążenie dłużnika odpowiedzialnością za niewykonanie lub nienależyte wykonanie zobowiązania „bez względu na przyczyny" 27 , chyba że wykładnia umowy pozwoli ustalić rzeczywistą wolę stron ${ }^{28}$, co może dotyczyć np. umownego rozszerzenia odpowiedzialności za siłę wyższą, jeżeli wynika to z treści umowy ${ }^{29}$. Przyjąć należy, że wskazane określenie oznacza jednak, iż wszystkie przyczyny mogą stanowić podstawę odpowiedzialności dłużnika. Takie postanowienie powoduje, że dłużnik odpowiada za szkodę bez względu na przyczynę, która spowodowała niewykonanie lub nienależyte wykonanie zobowiązania. W tej sytuacji nie ma potrzeby enumeratywnie wymieniać poszczególnych okoliczności, np. wystarczy, że „dłużnik odpowiada za opóźnienie", a więc bez względu na to, czy ponosi odpowiedzialność za okoliczności, których następstwem jest nieterminowe wykonanie zobowiązania.

Taka konstrukcja może dotyczyć zarówno niewykonania lub nienależytego wykonania samego przedmiotu zobowiązania, a więc zwykle umowy (np. co do jakości), jak i jej niewykonania w terminie. Oznacza to

27 Zob. np. W. Popiołek, w: Kodeks cywilny, t. 2. Komentarz..., art. 473, Nb 1; W. Borysiak, w: Kodeks cywilny. Komentarz, red. K. Osajda, art. 473, Nb 27; Z. Gawlik, w: Kodeks cywilny. Komentarz, red. A. Kidyba, t. 3, cz. 1, Warszawa 2014, art. 473, Nb 4, przy czym W. Popiołek dopuszcza możliwość określenia odpowiedzialności bezwzględnej typu gwarancyjnego.

28 Zob. K. Zagrobelny, w: Kodeks cywilny. Komentarz, red. E. Gniewek, P. Machnikowski, Warszawa 2016, art. 473, s. 965; F. Zoll, w: System Prawa Prywatnego, t. 6. Prawo zobowiqzań - część ogólna, red. A. Olejniczak, Warszawa 2014, s. 1127-1128.

29 J. Jastrzębski, O umownych modyfikacjach podstawy odpowiedzialności odszkodowawczej dtużnika, Kwartalnik Prawa Prywatnego 2007, t. 16, nr 3, s. 826-827. 
wprowadzenie do umowy zastrzeżenia o charakterze gwarancyjnym (nazywanym również zobowiązaniem gwarancyjnym ${ }^{30}$ czy karą gwarancyjną), które należy odróżnić od kary umownej. Konsekwencją jest absolutna odpowiedzialność dłużnika, a granice konstruowania takiego postanowienia wyznacza art. $353^{1}$ K.c. Ponieważ zawiera ono całkowite zanegowanie ogólnych zasad odpowiedzialności dłużnika, powinno zostać rozważone przy zastosowaniu art. 58 § 2 K.c. Jeżeli natomiast dotyczyłoby takiego rozszerzenia odpowiedzialności konsumenta, z całą pewnością byłaby to przynajmniej klauzula abuzywna (art. $385^{1} \S 1$ K.c.). Postanowienie to jest również nieważne $\mathrm{w}$ zakresie, $\mathrm{w}$ którym dotyczy odpowiedzialności za szkodę wyrządzoną z powodu okoliczności leżących po stronie wierzyciela, o czym była mowa powyżej.

Jeżeli zatem strony określą w umowie, że dłużnik odpowiada „za uchybienie terminu” lub „bez względu na przyczynę niewykonanie lub niewłaściwe wykonanie zobowiązania", wprowadzają zastrzeżenie o charakterze gwarancyjnym. W tej sytuacji dłużnik nie może zwolnić się przez wykazanie konkretnej okoliczności powodującej niewykonanie lub nienależyte wykonanie zobowiązania (chyba że jest to okoliczność, za którą odpowiada wierzyciel) albo że dochował należytej staranności. Jak podkreśla się w orzecznictwie, odpowiedzialność dłużnika bez względu na przyczynę niewykonania zobowiązania powinna być w umowie wyraźnie określona, z uwagi na to, że nie ma podstaw do dorozumiewania rozszerzonej odpowiedzialności dłużnika ${ }^{31}$. Nie można bowiem zapominać, że zastrzeżenie gwarancyjne stanowi bardzo istotne odstępstwo od ogólnych zasad odpowiedzialności, będąc instytucją nienazwaną prawa cywilnego (w przeciwieństwie do kary umownej). Ma to wpływ na wykładnię umowy, gdyż skoro nie można domniemywać rozszerzenia odpowiedzialności, wszelkie wątpliwości powinny być tłumaczone na korzyść kary umownej. Innymi słowy, jeżeli postanowienie umowne daje podstawy do interpretacji, ta powinna być dokonywana w kierunku uznania, że mamy do czynienia z karą umowną, a nie zastrzeżeniem gwarancyjnym.

30 Jest to określenie nieprecyzyjne, gdyż nie chodzi tu o klasyczne zobowiązanie o charakterze gwarancyjnym.

31 Zob. np. wyroki SN: z dnia 6 października 2010 r., II CSK 180/10, LEX nr 970070 oraz z dnia 16 stycznia 2013 r., II CSK 331/12, LEX nr 1293724; wyrok SA w Warszawie z dnia 15 kwietnia 2014 r., I ACa 1435/13, LEX nr 1461195; wyrok SA w Katowicach z dnia 22 czerwca 2018 r., V AGa 167/18, LEX nr 2524871; wyrok SA w Poznaniu z dnia 6 lipca 2018 r., I AGa 108/18, LEX nr 2546252, przy czym błędnie mowa jest o karze umownej. 
Słusznie zatem podkreśla się, że samo użycie - dla określenia przyczyn odpowiedzialności odszkodowawczej - sformułowania „za opóźnienie" nie może być wystarczające do przyjęcia, że zgodną wolą stron było obciążenie dłużnika rozszerzonym zakresem odpowiedzialności. Decydujące znaczenie należy bowiem przypisać intencji podmiotów tworzących stosunek prawny, a nie literalnemu brzmieniu umowy, co wynika z art. $65 \S 2$ K.c. ${ }^{32}$ Wszelkie postanowienia typu: „W wypadku opóźnienia w wykonaniu przez wykonawcę robót inwestorowi będzie przysługiwała kara umowna 1\% wynagrodzenia za każdy dzień opóźnienia" (w praktyce tego rodzaju postanowienie $\mathrm{w}$ umowach występuje bardzo często) powinny być interpretowane $w$ ten sposób, że dotyczą kary umownej związanej ze zwłoką (art. 476 K.c.), a więc opóźnieniem kwalifikowanym, co oznacza, że dłużnik ma możliwość zwolnić się od odpowiedzialności, jeżeli wykaże, że nie wykonał zobowiązania w terminie z przyczyn, za które nie ponosi odpowiedzialności. Nie ma bowiem możliwości rozszerzenia kary umownej do granic odpowiedzialności absolutnej, a skoro strony używają tej instytucji w umowie, to wykładnia oświadczeń woli nie powinna pomijać tego aspektu. Użycie słowa „opóźnienie” nie przesądza więc, że chodzi o opóźnienie zwykłe, ale właśnie o zwłokę, do czego sąd powinien dojść w drodze wykładni umowy. Zamienne posługiwanie się w umowie pojęciami „zwłoka” i „opóźnienie” tym bardziej powinno prowadzić do takiego wniosku.

Jeżeli (w powyższym przykładzie) strony zastąpią wyrażenie „kara umowna" słowem „kwota”, również nie jest to wystarczające do uznania wprowadzenia zastrzeżenia gwarancyjnego, jeśli z innych postanowień umowy wynika, że strony nie przyjęły absolutnej odpowiedzialności dłużnika. Jedynie wyraźne wskazanie przez strony, że dłużnik nie może zwolnić się z zapłaty określonej kwoty przez wykazanie, iż nie ponosi odpowiedzialności za niewykonanie lub nienależyte wykonanie zobowiązania (w tym w terminie), może prowadzić do wniosku, że nastąpiło odstępstwo od ogólnych zasad odpowiedzialności. Jeżeli istnieje konieczność dokonania wykładni oświadczeń woli, to wszelkie wątpliwości powinny prowadzić do wniosku, że strony zastrzegły karę umowną. Przykładowo, jeżeli w umowie zastrzeżono, że w przypadku niewykonania umowy

32 Zob. wyrok SA w Katowicach z dnia 22 czerwca 2018 r., V AGa 167/18, LEX nr 2524871; wyrok SA w Białymstoku z dnia 15 lutego 2019 r., I ACa 548/18, LEX nr 2669364. 
$\mathrm{w}$ terminie przez jedną ze stron druga strona będzie mogła naliczyć karę umowną „bez względu na przyczynę niewykonania umowy w terminie”, to zachodzi sprzeczność między istotą kary umownej a brakiem możliwości zwolnienia się przez dłużnika. Takie postanowienie należy uznać za częściowo nieważne (art. 58 § 1 i 3 w zw. z art. $353^{1}$ K.c.) - w zakresie niemożności zwolnienia się dłużnika, jako sprzeczne z właściwością (naturą) stosunku, czyli kary umownej.

\section{Zastrzeżenie gwarancyjne a przepisy o karze umownej}

W orzecznictwie niezasadnie mówi się o karze umownej, gdy dłużnik odpowiada bez względu na przyczynę niewykonania lub nienależytego wykonania zobowiązania - tak Sąd Najwyższy np. wyroku z dnia 16 stycznia 2013 r. ${ }^{33}$ To orzeczenie dotyczyło kary umownej „za opóźnienia w wykonaniu przedmiotu umowy". Sąd Najwyższy wskazał, że kara umowna może być zastrzeżona w kontrakcie zarówno za zwłokę, jak i (niezasadnie) za tzw. opóźnienie proste, aby następnie rozważać możliwość zwolnienia się przez dłużnika od odpowiedzialności przy zastrzeżeniu kary umownej za opóźnienie z uwagi na brak odpowiedzialności dłużnika za przyczyny, które spowodowały niewykonanie umowy w terminie. Gdyby faktycznie kara umowna mogła zostać zastrzeżona za opóźnienie, a więc za samo uchybienie terminowi (bez względu na przyczynę), to niedopuszczalne byłoby badanie, czy do niewykonania zobowiązania w terminie doszło z przyczyn, za które dłużnik nie ponosi odpowiedzialności.

W związku z tym "kara umowna za opóźnienie” jest to albo kara umowna za zwłokę, albo zastrzeżenie gwarancyjne (ze wskazaniem, że chodzi o tę pierwszą instytucję). Swoboda umów nie może prowadzić do zmiany właściwości instytucji prawa cywilnego w sposób wypaczający jej sens, a taką byłaby właśnie kara umowna za opóźnienie. Czym innym jest kara umowna, z zapłaty której dłużnik może się zwolnić, wykazując brak odpowiedzialności za przyczyny powodujące niewykonanie lub nienależyte wykonanie zobowiązania, nawet jeżeli strony określą pewne sytuacje wyłączające taką obronę dłużnika, a czym innym zastrzeżenie, które

33 II CSK 331/12, LEX nr 1293724; zob. też wyrok SA w Warszawie z dnia 15 kwietnia 2014 r., I ACa 1435/13, LEX nr 1461195. 
w ogóle wyłącza możliwość zwolnienia się dłużnika z odpowiedzialności. Należy przy tym podkreślić, że o zastosowaniu instytucji nie decyduje (aczkolwiek może mieć wpływ przy wykładni oświadczeń woli) nazwa nadana przez strony, ale treść umowy (i jej poszczególnych postanowień).

Jest to istotne, ponieważ jeżeli strony wprowadzą do umowy zastrzeżenie gwarancyjne, to oprócz tego, że oznacza to niemożność zwolnienia się przez dłużnika $\mathrm{z}$ odpowiedzialności w razie niewykonania lub nienależytego wykonania zobowiązania (ale nieważne będzie postanowienie umowne - $\mathrm{w}$ całości lub w części - jeżeli chodzi o przyczyny leżące po stronie wierzyciela, co zawiera się w pojęciu „za opóźnienie" czy „bez względu na przyczynę"), to - jak wskazał Sąd Najwyższy również w ww. wyroku - do takiego zastrzeżenia nie mają zastosowania przepisy regulujące karę umowną. Dodać należy, że brak jest podstaw, aby stosować je chociażby per analogiam. Jest to bowiem dodatkowe zastrzeżenie umowne, które strony mogą ukształtować zgodnie z art. $353^{1}$ K.c.

Niemożność stosowania przepisów o karze umownej w odniesieniu do zastrzeżenia gwarancyjnego oznacza również:

1) brak konieczności oznaczenia zastrzeżenia gwarancyjnego jako „określonej sumy pieniężnej”, co powoduje większą elastyczność $\mathrm{w}$ tym przedmiocie niż $\mathrm{w}$ odniesieniu do kary umownej, jednak może prowadzić do zastosowania art. 58 § 2 K.c., jeżeli sąd uzna, np. że nieprecyzyjne oznaczenie kwoty prowadzi do naruszenia zasad współżycia społecznego z uwagi na niemożność ustalenia ewentualnego obciążenia dłużnika (co może wpływać na ryzyko kontraktowe), czy też z uwagi na uzależnienie jej wysokości od obrotu wypracowanego przez dłużnika ${ }^{34}$;

2) częstszą możliwość zastosowania art. 58 § 2 K.c., szczególnie gdy zastrzeżenie gwarancyjne zostało zastrzeżone na rzecz jednej ze stron, przy ograniczeniu odpowiedzialności drugiej strony i braku negocjacji umowy;

3) częstszą możliwość zastosowania art. 5 K.c., co w przypadku kary umownej jest zupełnie wyjątkowe ${ }^{35}$;

34 Zob. też wyrok SN z dnia 23 czerwca 2017 r., I CSK 634/16, LEX nr 2381192.

35 Zob. wyrok SN z dnia 26 października 2016 r., III CSK 312/15, LEX nr 2186574; odmiennie wyrok SA w Lublinie z dnia 15 stycznia 2013 r., I ACa 655/12, LEX nr 1286575 i wyrok SA w Warszawie z dnia 14 grudnia 2017 r., I ACa 1591/16, LEX nr 2439580. 
4) niemożność zastosowania instytucji miarkowania (art. 484 § 2 K.c.), a więc sąd nie może na tej podstawie obniżyć wysokości świadczenia z tytułu zastrzeżenia gwarancyjnego;

5) niestosowanie instytucji odszkodowania uzupełniającego (art. 484 $\S 1$ zd. 2 K.c.), a zatem w każdej sytuacji wierzyciel może dochodzić (na zasadach ogólnych) odszkodowania ponad kwotę zastrzeżenia gwarancyjnego.

Niezbędne jest określenie zobowiązania, z którym zastrzeżenie gwarancyjne zostaje powiązane. Niedopuszczalne jest natomiast jego skonstruowanie na wypadek niewykonania lub nienależytego wykonania zobowiązania pieniężnego, analogicznie jak w przypadku kary umownej $^{36}$, która nie może zostać również ważnie zastrzeżona na wypadek odstąpienia od umowy z powodu niewykonania zobowiązania o charakterze pieniężnym ${ }^{37}$. Powiązanie zastrzeżenia gwarancyjnego ze świadczeniem pieniężnym oznaczałoby - tak jak w przypadku kary umownej - obejście przepisów o odsetkach, w tym w szczególności możliwość obejścia odsetek maksymalnych za opóźnienie (art. 481 $\S 2^{2}$ K.c.), co prowadziłoby do tzw. lichwy. To odsetki stanowią zabezpieczenie wierzyciela $\mathrm{w}$ przypadku niespełnienia przez dłużnika w terminie świadczenia pieniężnego.

\section{Zakończenie}

Powyższe rozważania uwidoczniły istotne różnice pomiędzy dwiema omawianymi instytucjami prawa cywilnego, które mieszczą się w pojęciu kontraktowej odpowiedzialności odszkodowawczej. Nie tylko w teorii prawa, ale przede wszystkim w praktyce ich rozróżnienie ma bardzo istotne znaczenie dla stron umowy. O ile jednak kara umowna jest klasyczną instytucją prawa cywilnego, to zastrzeżenie gwarancyjne może zostać wprowadzone do umowy na zasadzie wynikającej z art. $353^{1}$ K.c. Z punktu

$36 \mathrm{~W}$ tym zakresie art. 483 § 1 K.c. ma charakter bezwzględnie obowiązujący zob. np. wyrok SN z dnia 21 sierpnia 2008 r., IV CSK 202/08, LEX nr 466003; wyrok SA w Katowicach z dnia 23 lipca 2013 r., V ACa 233/13, LEX nr 1362696.

37 Uchwała 7 sędziów SN z dnia 20 listopada 2019 r., III CZP 3/19, Monitor Prawniczy 2020, nr 1, s. 3. 
widzenia wierzyciela zastrzeżenie gwarancyjne może być rozpatrywane jako lepiej chroniące jego uzasadnione interesy, gdyż wprowadza do umowy absolutną odpowiedzialność dłużnika (z zastrzeżeniem braku odpowiedzialności za szkody powstałe z przyczyn leżących po stronie wierzyciela). Kara umowna daje natomiast dłużnikowi szersze możliwości zwolnienia się od odpowiedzialności odszkodowawczej, a więc może być postrzegana jako słabiej chroniąca interesy wierzyciela. Pamiętać jednak należy, że im dalej idące odstępstwo od kodeksowych zasad odpowiedzialności dłużnika, w wyniku jej rozszerzenia (jak ma to miejsce w przypadku zastrzeżenia gwarancyjnego), tym większa „szansa” uznania takiego postanowienia za nieważne, co może być niekorzystne dla wierzyciela. W konkretnej sytuacji zastrzeżenie kary umownej może być zatem korzystniejsze dla wierzyciela.

\section{Bibliografia}

Borysiak W., w: Kodeks cywilny. Komentarz, red. K. Osajda, 2020 [baza danych Legalis].

Gawlik Z., w: Kodeks cywilny. Komentarz, t. 3, cz. 1, red. A. Kidyba, Warszawa 2014. Janiszewska B., Klauzula generalna dobrych obyczajów w znowelizowanych przepisach kodeksu cywilnego, Przegląd Prawa Handlowego 2003, nr 10.

Jastrzębski J., Kara umowna, Warszawa 2006.

Jastrzębski J., O umownych modyfikacjach podstawy odpowiedzialności odszkodowawczej dłużnika, Kwartalnik Prawa Prywatnego 2007, t. 16, nr 3.

Pajor T., Odpowiedzialność dłużnika za niewykonanie zobowiazania, Warszawa 1982.

Piekarski M., w: Kodeks cywilny. Komentarz, t. 2, red. Z. Resich, J. Ignatowicz, J. Pietrzykowski, I. Bielski, Warszawa 1972.

Popiołek W., w: Kodeks cywilny, t. 2. Komentarz. Art. 450-1088. Przepisy wprowadzajace, red. K. Pietrzykowski, Warszawa 2018.

Rott-Pietrzyk E., Klauzula generalna rozsadku w kodeksie cywilnym, Kwartalnik Prawa Prywatnego 2005, t. 14, nr 3.

Stefanicki R., Dobre obyczaje w prawie polskim, Przegląd Prawa Handlowego 2002, nr 5.

Szanciło T., w: Kodeks cywilny. Komentarz, red. M. Załucki, Warszawa 2019.

Tomaszek A., Dobre obyczaje w działalności gospodarczej, Palestra 1997, nr 9-10. 
Warkałło W., Klauzule wyłaczające odpowiedzialność za szkodę a ubezpieczenie odpowiedzialności cywilnej, Ruch Prawniczy, Ekonomiczny i Socjologiczny 1974, nr 3.

Wiśniewski T., w: Kodeks cywilny. Komentarz, t. 3. Zobowiąania. Część ogólna, red. J. Gudowski, Warszawa 2018.

Zagrobelny K., w: Kodeks cywilny. Komentarz, red. E. Gniewek, P. Machnikowski, Warszawa 2016.

Zoll F., w: System Prawa Prywatnego, t. 6. Prawo zobowiązan - część ogólna, red. A. Olejniczak, Warszawa 2014.

\section{Streszczenie}

Kara umowna, która stanowi jedno z najczęściej stosowanych tzw. dodatkowych zastrzeżeń umownych, pozwala zabezpieczyć interes wierzyciela, niemniej dłużnik ma różne możliwości, aby zwolnić się z obowiązku jej zapłaty albo zapłacić kwotę niższą niż wynikałaby z postanowienia umownego. Przepisy regulujące karę umowną pozwalają jednak na modyfikację instytucji prawa cywilnego w kierunku rozszerzenia okoliczności, w których wierzyciel będzie uprawniony obciążyć dłużnika karą umowną. W wyniku tego może dojść do znacznego odstępstwa od ustawowych zasad związanych ze stosowaniem kar umownych, prowadząc w skrajnym przypadku do rozszerzenia odpowiedzialności dłużnika do granic odpowiedzialności absolutnej. Daje to możliwość wprowadzenia do umowy tzw. zastrzeżenia gwarancyjnego. W artykule została podjęta próba rozróżnienia tych dwóch instytucji prawa cywilnego, wskazania ich cech wspólnych, ale przede wszystkim różnic, jak i zasad wprowadzenia tych postanowień do umowy. Modyfikacja zasad odpowiedzialności dłużnika z tytułu kar umownych nie może bowiem pomijać granic, o których mowa w art. $353^{1}$ Kodeksu cywilnego. Zastrzeżenie gwarancyjne, jako bardzo daleko idące odstępstwo od kodeksowej konstrukcji kary umownej, powinno być wprowadzane do umowy z dużą ostrożnością.

Słowa kluczowe: wierzyciel, dłużnik, odpowiedzialność odszkodowawcza, kara umowna, zastrzeżenie gwarancyjne, zwłoka

\section{CONTRACTUAL PENALTY AND WARRANTY CLAIM}

\section{Summary}

Contractual penalty is one of the most commonly used so-called additional contractual clauses, especially in professional trading. Such a provision, properly 
constructed, in accordance with art. 483-484 of the Civil Code, significantly secures the creditor's interest. The possibility of modifying the extent of the debtor's liability means that liability for contractual penalties may also be based on circumstances other than those provided for in Article 471 of the Civil Code. In extreme cases, this leads to the debtor's liability being extended to the limit of absolute liability. The purpose of this study is to distinguish between two civil law institutions that define the limits of the debtor's liability for non-performance or improper performance of an obligation, especially since the warranty claim was not discussed in the doctrine.

Key words: creditor, debtor, liability for damages, contractual penalty, warranty claim, delay

\section{ДОГОВОРНАЯ А ГАРАНТИЙНАЯ НЕУСТОЙКИ}

\section{Резюме}

Договорная неустойка, которая является одним из наиболее часто используемых так называемых «дополнительных условий» в договорах, помогает обеспечить интерес кредитора, однако у должника есть различные возможности освободиться от обязательства по уплате неустойки или уплатить меньшую сумму, чем это вытекало бы из договора. Положения, регулирующие договорную неустойку, допускают, однако, изменение гражданско-правового института в сторону расширения обстоятельств, при которых кредитор будет вправе взыскать с должника договорную неустойку. В результате может произойти значительное отклонение от установленных законом правил, связанных с применением договорной неустойки, что в крайнем случае приведет к расширению ответственности должника до пределов абсолютной ответственности. Это дает возможность внести в договор так называемую гарантийную неустойку. В статье была предпринята попытка разграничить эти два института гражданского права, указать их общие черты, но прежде всего различия, а также правила внесения этих положений в договор. Изменение правил ответственности должника по договорной неустойке не может не учитывать пределы, указанные в статье 3531 Гражданского кодекса. Гарантийная неустойка, как очень далеко идущее отклонение от установленной Кодексом конструкции договорной неустойки, должна вводиться в договор с большой осторожностью.

Ключевые слова: кредитор, должник, ответственность за убытки, договорная неустойка, гарантийная неустойка, просрочка 